NBER WORKING PAPER SERIES

\title{
IS THE TECHNOLOGY-DRIVEN REAL BUSINESS CYCLE HYPOTHESIS DEAD? SHOCKS AND AGGREGATE FLUCTUATIONS REVISITED
}

\author{
Neville Francis \\ Valerie A. Ramey \\ Working Paper 8726 \\ http://www.nber.org/papers/w8726 \\ NATIONAL BUREAU OF ECONOMIC RESEARCH \\ 1050 Massachusetts Avenue \\ Cambridge, MA 02138 \\ January 2002
}

We have benefited from helpful discussions with Craig Burnside, Wouter den Haan, Graham Elliot, James Hamilton, Boyan Jovanovic, Garey Ramey, and Matthew Shapiro, as well as seminar participants at UC Riverside, UCLA, Columbia, NY Fed, and NYU. Jordi Galí kindly provided his data for replication purposes. Valerie Ramey gratefully acknowledges support from National Science Foundation Grant SBR-9617437 through the National Bureau of Economic Research. The views expressed herein are those of the authors and not necessarily those of the National Bureau of Economic Research.

(C) 2002 by Neville Francis and Valerie A. Ramey. All rights reserved. Short sections of text, not to exceed two paragraphs, may be quoted without explicit permission provided that full credit, including $\odot$ notice, is given to the source. 
Is the Technology-Driven Real Business Cycle Hypothesis Dead?

Shocks and Aggregate Fluctuations Revisited

Neville Francis and Valerie A. Ramey

NBER Working Paper No. 8726

January 2002

JEL No. E3

\begin{abstract}
In this paper, we re-examine the recent evidence that technology shocks do not produce business cycle patterns in the data. We first extend Galí's (1999) work, which uses long-run restrictions to identify technology shocks, by examining whether the identified shocks can be plausibly interpreted as technology shocks. We do this in three ways. First, we derive additional long-run restrictions and use them as tests of overidentification. Second, we compare the qualitative implications from the model with the impulse responses of variables such as wages and consumption. Third, we test whether some standard "exogenous" variables predict the shock variables. We find that oil shocks, military build-ups, and Romer dates do not predict the shock labeled "technology." We then show ways in which a standard DGE model can be modified to fit Galí's finding that a positive technology shock leads to lower labor input. Finally, we re-examine the properties of the other key shock to the system.
\end{abstract}

Neville Francis

Department of Economics

Lehigh University

620 Taylor Street

Bethlehem, PA 18015

nef2@lehigh.edu
Valerie A. Ramey

Department of Economics, 0508

University of California, San Diego

9500 Gilman Drive

La Jolla, CA 92093-0508

and NBER

vramey@ucsd.edu 


\section{Introduction}

Real business cycle theory assigns a central role to technology shocks as the source of aggregate fluctuations. As King and Rebelo (1999) discuss in "Resuscitating Real Business Cycles," when persistent technology shocks are fed through a standard real business cycle model, the simulated economy displays patterns similar to those exhibited by actual business cycles. While the last decade has seen the addition of other types of shocks in these models, such as monetary policy and government spending, none has been shown to be a central impulse to business cycles.

A trio of recent papers has called into question the notion that technology shocks have anything to do with business cycles. Although they use very different methods, Galí (1999), Shea (1998) and Basu, Kimball, and Fernald (1999) all present the same result: positive technology shocks appear to lead to declines in labor input. ${ }^{1}$ Galí identifies technology shocks using long-run restrictions in a structural VAR; Shea uses data on patents and R\&D; and Basu, Kimball and Fernald identify technology shocks by estimating Hall-style regressions with proxies for utilization. In all cases, they find significant negative correlations of hours with the technology shock. $^{2}$

Galí's paper also studies the effects of the non-technology shocks, which he suggests might be interpreted as demand shocks. These shocks produce the typical business cycle

\footnotetext{
${ }^{1}$ The fall in labor input is a long run response in Shea. Labor rises in the short run and then eventually falls.

${ }^{2}$ Shapiro and Watson (1988) uncovered this result a decade ago, but it apparently went unnoticed. (See Figures 2 and 5 of their paper.)
} 
comovement between output and hours. In response to a positive shock, both output and hours show a rise in the typical hump-shaped pattern. Productivity also rises, but only temporarily.

We view the empirical results of these papers to be potential paradigm shifters. If these results prove to be robust, the idea of technology-driven business cycles loses all of its appeal. If it is "demand" shocks that are producing the classic business cycle patterns, then renewed emphasis should be devoted to understanding the imperfections in the economy that allow these shocks to have these types of effects.

In this paper, we re-examine the effects of shocks identified using long-run restrictions. First, we impose two additional long-run restrictions, allowing us to test formally the overidentifying restrictions. Second, we provide evidence on the plausibility of Gali's identification scheme by studying the effects of identified technology shocks on other economic variables. We also analyze whether the qualitative effects of the shocks on other variables are economically plausible by comparing the effects to those predicted by a standard growth model.

We then study whether suitably altered dynamic general equilibrium models can explain the facts. We present examples of two models that can explain these effects of technology shocks, without resorting to assumptions about sticky prices. One model assumes Leontief technology with variable utilization and the other model includes habit formation in consumption and adjustment costs in investment. Despite their ability to explain these effects, the modified models do not resuscitate technology shocks as the driving force of business cycles. In that sense, the original technology-driven real business cycle hypothesis does appear to be dead.

In the last part of the paper we study the broader implications of Galí's "demand shocks," which are identified as the shocks to labor that are uncorrelated with the technology shock. According to Galís work, these shocks are the ones that produce the standard business cycle 
comovements and match well with NBER business cycles. We examine the effects of these shocks on our broader list of variables, as well as their correlation with key exogenous variables.

\section{Effects of a Technology Shock in a Standard DGE Model}

To assess the plausibility of the interpretation of the shocks, we begin by highlighting the predictions about how permanent technology shocks should affect other key variables in the economy of a standard DGE (dynamic general equilibrium) model. We employ a model that is a simple extension of the model presented in the working paper version of King, Plosser, Stock and Watson (1987). This model produces two additional long-run restrictions, as well as qualitative predictions for several other variables.

Consider the following neoclassical model with technology shocks:

$$
\begin{array}{ll}
Y_{t}=A_{t} N_{t}^{\alpha} K_{t}^{1-\alpha} & \text { Production Function } \\
K_{t+1}=(1-\delta) K_{t}+I_{t} & \text { Capital Accumulation } \\
C_{t}+I_{t} \leq Y_{t} & \text { Resource Constraint } \\
U\left(C_{t}, N_{t}\right)=\phi \ln \left(C_{t}\right)+v\left(N_{t}\right) & \text { Utility }
\end{array}
$$

The variables have the standard definitions: $Y$ is output, $A$ is an exogenous process for total factor productivity, $K$ is capital, $N$ is labor input, $\delta$ is the depreciation rate, $I$ is investment, and $C$ is consumption. We assume that the production function exhibits constant returns to scale, and that $v(N)$ is decreasing and quasi-convex in $N$. The representative consumer maximizes the expected present discounted value of utility, with discount factor $\beta$. 
A key assumption in the Galí analysis is that the technology shock has a unit root. We capture this feature in the model with the assumption:

$$
\ln \left(A_{t}\right)=\mu+\ln \left(A_{t-1}\right)+\eta_{t}
$$

where $\eta$ is a stationary shock. $\eta$ corresponds to the shock that the structural VAR seeks to uncover.

As discussed by King et al, since the economy has a stochastic steady state, one needs to transform the model so that it has a stationary distribution. In this case, we divide $K_{t}, I_{t}$, and $C_{t}$ by $A_{t}{ }^{1 / \alpha}$ and modify the problem accordingly. Denoting the decision rules governing the transformed (stationary) capital, investment and consumption variables by lower case letters, it is easy to show that the economy evolves according to:

$$
\begin{aligned}
& \ln K_{t+1}=\ln \left[(1-\delta) k_{t}+i\left(k_{t}\right)\right]+\frac{1}{\alpha} \ln A_{t} \\
& \ln Y_{t}=(1-\alpha) \ln k_{t}+\alpha \ln N\left(k_{t}\right)+\frac{1}{\alpha} \ln A_{t} \\
& \ln C_{t}=\ln c\left(k_{t}\right)+\frac{1}{\alpha} \ln A_{t} \\
& \ln I_{t}=\ln i\left(k_{t}\right)+\frac{1}{\alpha} \ln A_{t} \\
& \ln N_{t}=\ln N\left(k_{t}\right) \\
& \ln \frac{Y_{t}}{N_{t}}=(1-\alpha) \ln k_{t}-(1-\alpha) \ln N\left(k_{t}\right)+\frac{1}{\alpha} \ln A_{t} \\
& \ln \frac{W_{t}}{P_{t}}=\ln \alpha+\ln \frac{Y_{t}}{N_{t}} \\
& \quad=\ln \alpha+(1-\alpha) \ln k_{t}-(1-\alpha) \ln N\left(k_{t}\right)+\frac{1}{\alpha} \ln A_{t}
\end{aligned}
$$


All of the terms involving functions of $k_{t}=K_{t} / A_{t}{ }^{1 / \alpha}$ are, by construction, stationary. In this simple model, $\ln A_{t}$ is the only source of stochastic trend, and it is common to all variables, except for labor input.

Inspection of the equations reveals that a positive shock $\eta$ to the $\ln A_{t}$ equation should lead to permanent increases in labor productivity, output, consumption, investment, real wages, and capital. In contrast, such a shock has no long-run effect on hours because the specification of preferences forces the wealth and substitution effects on labor supply to cancel exactly.

To determine the features that distinguish technology shocks from other shocks, let us compare these effects to those from other possible sources of permanent shocks or stochastic trends in these kinds of model. Two leading candidates that have been studied in the literature are permanent changes in government purchases and shifts in preferences (e.g. Baxter and King (1991, 1993), Ahmed and Yoo (1995)). Both of these shocks work by shifting labor supply, and they are predicted to have permanent effects on output, consumption, investment and capital. In contrast, they should have only temporary effects on labor productivity or real wages: If labor supply rises, firms accumulate capital until labor productivity and real wages return to their previous values. Thus, one of the distinguishing features of a technology shock is its permanent effect on labor productivity and real wages.

A third type of shock is a monetary shock. In most models, a monetary shock has a permanent effect only on the price level. Its effect on real variables such as output and productivity is fleeting.

Galí uses the insight that only technology shocks should have a permanent effect on productivity to identify technology shocks in the data. Our discussion of the model reveals two more long-run restrictions implied by standard theory. First, analogous to the prediction for 
labor productivity, only technology shocks can have a permanent effect on wages. Second, while permanent government spending shocks and preference shifts will have a permanent effect on hours per capita, technology shocks should have only a temporary effect on hours. All real business cycle models, including the one above, specify a utility function in which the income and substitution effects of an increase in the real wage exactly cancel. This feature is necessary to match the growth facts: over the last century there has been a significant increase in the real wage accompanied by virtually no change in hours per capita. Thus, a complementary long-run restriction for identifying a technology shock is that the technology shock should have no longrun effect on hours.

There are no analogous long-run restrictions with respect to the other variables. All three kinds of shocks can have permanent effects on output, consumption, and investment. We can, however, check whether the response of these variables to an identified technology shock is qualitatively in line with the model's predictions.

Various permutations of these long-run restrictions appear in the literature. Most papers discuss long-run restrictions derived in the context of the traditional aggregate demand and aggregate supply framework. Table 1 shows the long-run restrictions imposed by various researchers. Many previous papers have assumed that aggregate demand shocks cannot effect hours in the long-run. While monetary shocks satisfy this assumption in most models, fiscal shocks do not since they can have long-run effects on both output and hours in the neoclassical model. Thus, it is unclear how to interpret the aggregate demand shocks identified in these models or how fiscal shocks would be classified.

The paper that imposes the widest range of available long-run restrictions is Fleischman's (2000) study of the cyclicality of the real wage. As indicated in Table 1, Fleischman uses both 
the Shapiro-Watson restriction that technology shocks and AD shocks cannot affect hours in the long-run, as well as Galí's restriction that only technology shocks have a long-run effect on productivity. Fleischman also imposes the long-run restrictions that only oil price shocks and technology shocks have permanent effects on real wages.

Our analysis differs from Fleischman's in four ways. First, we do not impose the AD restrictions derived from traditional Keynesian models, since we find them hard to interpret. Second, we do not include oil prices directly in the model, although we study their correlations with the identified shocks. Third, we show that some of the results are sensitive to the type of cointegrating vector used in the analysis. Fourth, and most importantly, we study the response of variables such as hours, consumption, and investment, as well as the correlation between real wages and output that is the focus of Fleischman's analysis.

In the next section, we investigate how the results vary when we use different long-run identification schemes. We then impose all of the available long-run restrictions and formally use them as tests of overidentifying restrictions. Finally, we investigate whether the other variables react to the identified shock in the way predicted by the model.

\section{Empirical Framework and Results}

\section{A. Econometric Framework}

We begin by reviewing Galís baseline model, and then extend it to incorporate more restrictions and more variables. In this model, the technology shock is identified as the only shock that can have permanent effects on productivity. This assumption is relatively unrestrictive as it allows for temporary effects of non-technology shocks on measured 
productivity, through variations in capital utilization and effort. Galís basic framework consists of the following bivariate model of labor productivity and hours:

$$
\left[\begin{array}{l}
\Delta x_{t} \\
\Delta n_{t}
\end{array}\right]=\left[\begin{array}{ll}
C^{11}(L) & C^{12}(L) \\
C^{21}(L) & C^{22}(L)
\end{array}\right]\left[\begin{array}{l}
\varepsilon_{t}^{z} \\
\varepsilon_{t}^{m}
\end{array}\right] .
$$

$x_{t}$ denotes the $\log$ of labor productivity, $n_{t}$ denotes the $\log$ of labor input, $\varepsilon^{z}$ denotes the technology shock, and $\varepsilon^{m}$ denotes the non-technology shock. $\mathrm{C}(\mathrm{L})$ is a polynomial in the lag operator. We invoke the usual assumption that $\varepsilon^{z}$ and $\varepsilon^{m}$ are orthogonal. The assumption identifying the technology shock implies that $C^{12}(1)=0$, which restricts the unit root in productivity to originate solely in the technology shock. Implicit in this specification, but not necessary for identification, is the assumption that the log of labor input has a unit root.

Another way to think about this restriction is through the estimation method suggested by Shapiro and Watson (1988). To impose Galí's long-run restriction, we estimate the following equations:

$$
\begin{aligned}
& \Delta x_{t}=\sum_{j=1}^{p} \beta_{x x, j} \Delta x_{t-j}+\sum_{j=0}^{p-1} \beta_{x n, j} \Delta^{2} n_{t-j}+\varepsilon_{t}^{z} . \\
& \Delta n_{t}=\sum_{j=1}^{p} \beta_{n n, j} \Delta n_{t-j}+\sum_{j=0}^{p} \beta_{n x, j} \Delta x_{t-j}+\theta \varepsilon_{t}^{z}+\varepsilon_{t}^{m} .
\end{aligned}
$$

As discussed by Shapiro and Watson (1988), imposing the long-run restriction is equivalent to restricting the other variables to enter the equation in double-differences. Because the current value of $\Delta^{2} n_{t}$ will be correlated with $\varepsilon_{t}^{z}$ in the first equation, one must use instrumental variables 
to estimate the equation. Using lags one through $\mathrm{p}$ of $\Delta x_{t}$ and $\Delta n_{t}$ as instruments yields estimates that are identical to those obtained using matrix methods.

The second shock to the system, $\varepsilon_{t}^{m}$, is identified by including the estimated residual from the first equation in the second equation, along with the standard lags of the variables, as shown in equation $(5 b)$. The estimated residual from this equation, $\varepsilon_{t}^{m}$, is identified as the "nontechnology" or "demand" shock.

Consider now the alternative long-run restriction involving real wages. Analogous to the case of labor productivity, only a technology shock should have a permanent effect on real wages. Thus, an alternative way to identify the technology shock is to substitute real wages for productivity to yield:

$$
\begin{aligned}
& \Delta w_{t}=\sum_{j=1}^{p} \beta_{w w, j} \Delta w_{t-j}+\sum_{j=0}^{p-1} \beta_{w n, j} \Delta^{2} n_{t-j}+\varepsilon_{t}^{z^{\prime}} . \\
& \Delta n_{t}=\sum_{j=1}^{p} \beta_{n n, j} \Delta n_{t-j}+\sum_{j=0}^{p} \beta_{n w, j} \Delta w_{t-j}+\varphi \varepsilon_{t}^{z^{\prime}}+\varepsilon_{t}^{m^{\prime}} .
\end{aligned}
$$

If technology shocks are indeed the sole shocks with long-run effects on wages and productivity, then $\varepsilon_{t}^{z}$ and $\varepsilon_{t}^{z^{\prime}}$ should have a correlation of unity, and both should be uncorrelated with $\varepsilon_{t}^{m}$ and $\varepsilon_{t}^{m^{\prime}}$

But we can go even farther by considering the third long-run restriction that technology shocks have no long-run effect on hours. We can thus create a shock that excludes permanent technology shocks. We impose this restriction by constraining $C^{21}(1)=0$ in equation (4) above. To impose this restriction in the IV (instrumental variable) framework, we estimate the hours 
equation with double differences of productivity, and insert the identified shock in the productivity equation as follows:

$$
\begin{aligned}
& \Delta x_{t}=\sum_{j=1}^{p} \beta_{x n, j} \Delta n_{t-j}+\sum_{j=0}^{p} \beta_{x x, j} \Delta x_{t-j}+\phi \varepsilon_{t}^{m^{\prime \prime}}+\varepsilon_{t}^{z^{\prime \prime}} . \\
& \Delta n_{t}=\sum_{j=1}^{p} \beta_{n n, j} \Delta n_{t-j}+\sum_{j=0}^{p-1} \beta_{n x, j} \Delta^{2} x_{t-j}+\varepsilon_{t}^{m^{\prime \prime}} .
\end{aligned}
$$

Note that Equation (7b) must be estimated before equation (7a) to create the error term as a regressor. The residual in equation (7b) should be orthogonal to the technology shock since the former can have a long-run effect on hours. Note, though, that in contrast to the previous systems, the residual in the productivity equation, $\varepsilon_{t}^{z^{\prime \prime}}$, may include other shocks in addition to the technology shock. For example, a monetary shock that has no long-run effect on hours would be included in $\varepsilon_{t}^{z^{\prime \prime}}$ and not in $\varepsilon_{t}^{m^{\prime \prime}}$. There is not a perfect correspondence between the shocks in system (7a) and (7b) and those from the previous systems.

The first set of empirical results will be based on these bivariate models. Later, we will also analyze models with more variables. We reserve the discussion of the larger models for the sections that do those analyses.

\section{B. Data}

We use quarterly data from 1947:1 to 2000:4 to estimate the model. For the series on labor productivity and labor input, we use the BLS series "Index of output per hour, business" and "Index of hours in business," respectively. These series are somewhat different from those 
used by Galí, who used total employee hours in nonagricultural establishments for labor input and GDP divided by this labor input measure for productivity. His labor input measure includes only private employee hours, but his GDP measure includes government. Thus, a shift toward more government output would appear to raise productivity because it would raise the numerator and lower the denominator in the productivity measure. We believe our measures to be more accurate, although as we show below, we obtain the same basic results as Galí. The real wage measure is the BLS measure of nominal hourly compensation in private business divided by the BLS deflator for private business. The other series are chain-weighted 1996 dollar NIPA series from the BEA Web site. All relevant variables are put on a per capita basis by dividing by the population age 16 and above.

In the baseline specification of the model, we assume that all variables have unit roots, an assumption not rejected by the data. We include four quarterly lags of each variable in the estimation, based on a BIC criterion.

Before turning to the estimation of the models, it is useful to remember the types of unconditional correlations displayed by the post-WWII data. These correlations constitute some of the key stylized facts of business cycle analysis. In growth rates, the correlation between the output and hours is 0.67 ; between output and productivity, 0.70 ; and between productivity and hours, -0.046 . The correlation is 0.50 between real wages and productivity, and -0.23 between real wages and hours (all in growth rates). 


\section{Comparison of Different Identification Schemes}

The first step is to determine how the effects of a technology shock differ across the three long-run identification schemes. To this end, we estimate models (5) - (7) separately and calculate the impulse responses.

Figures $1 \mathrm{~A}-1 \mathrm{C}$ show the effects of the identified technology shocks on productivity (or wages in system (6)) and hours. ${ }^{3}$ Figure 1A shows the impulse responses using Gali's identification scheme. Despite the changes in variables and the longer sample period, the results are very similar to his results. An identified technology shock leads to an immediate and permanent rise in productivity. In response to the same shock, hours worked declines and does not return to near normal for a year and a half.

Consider Figure 1B, which shows the effect of a technology shock identified as the only shock that permanently affects real wages. These results are consistent with the previous results: a technology shock leads to an immediate and permanent rise in real wages and a decline in hours. In this graph, hours show no tendency to return to their former levels.

Finally, Figure 1C shows the effect of a shock that does not have a permanent effect on hours. Recall that a technology shock would meet this criterion, but so also would a monetary shock. Thus, this shock is potentially a mixture of various types of shocks. Given this caveat, the results are surprisingly similar to the previous ones: productivity jumps immediately and permanently and hours fall in the short-run. Hours do show a quicker tendency to return to normal, taking about a year.

\footnotetext{
${ }^{3}$ The standard error bands were computed using a bootstrap Monte Carlo procedure with 1000 replications.
} 
Given our initial skepticism concerning long-run restrictions, we were surprised to find that technology shocks identified with three different long-run identification schemes produced reactions of hours and productivity (or wages) that were similar across the systems. In all three schemes, a positive technology shock appears to lead to a decline in hours for at least a year.

The next step is to specify a unified model in which the additional restrictions can be used as overidentification tests. The tests are a bit tricky because the two additional restrictions are incorporated in different ways. The first restriction on wages, in conjunction with Gali's restriction on labor productivity, implies that productivity and real wages should share a common stochastic trend, which is identified as the technology shock. In other words, labor productivity and real wages should be cointegrated (Engle and Granger (1987), Stock and Watson (1988)). Thus, the test of the joint restriction that technology shocks are the only shocks that have permanent effects on both productivity and real wages is a test of cointegration between the two variables.

The first row of Table 2 tests for a unit root in (the negative of) labor share, $x-w$. As shown in equation (3) of the theoretical model, theory predicts that not only should labor productivity and wages be cointegrated, but also that the cointegrating vector should be $(1,-1)$. In other words, the labor share should be stationary. As the table shows, the test supports the notion that labor share is indeed stationary; the p-value of the test of a unit root is 0.02 .

The second row of Table 2 tests directly for cointegration between productivity and wages and estimates the cointegrating vector. The results support the hypothesis that the two variables are cointegrated and that the cointegrating vector is $(1,-1.03649)$. The standard errors suggest that this vector is significantly different from $(1,-1){ }^{4} \quad$ As we shall show, the seemingly

\footnotetext{
${ }^{4}$ The coefficients are estimated using Dynamic OLS with optimal lead and lag selection. The standard errors are heteroscedastic and autocorrelation consistent standard errors based on a Bartlett kernel with 8 lags.
} 
small switch from -1 to -1.036 in the construction of the error correction term has a noticeable effect on its explanatory power, as well as some of the impulse response functions.

In sum, the evidence in favor of cointegration can be interpreted as evidence in favor of the joint restrictions on the effect of technology on productivity and wages. Wages and productivity share a common stochastic trend. Technological progress is a natural interpretation of that trend.

To test the third restriction concerning hours, we specify a trivariate vector errorcorrection model (VECM) which incorporates the other two restrictions. This model takes the form:

(8a) $y_{t}=C(L) u_{t}$,

where $y_{t}$ is a $3 \times 1$ vector consisting of labor productivity growth $\left(\Delta x_{t}\right)$, hours growth $\left(\Delta n_{t}\right)$, and the error correction term between productivity and wages $\left(x_{t}-\beta w_{t}\right) . u_{t}$ consists of the shocks $\varepsilon_{t}^{z}, \varepsilon_{t}^{m}, \varepsilon_{t}^{w}$, in that order.

To estimate the system properly, we should include $\mathrm{p}$ lags of labor productivity growth and real wage growth, plus one lag of the error correction term, or equivalently, $\mathrm{p}$ lags of labor productivity growth and $\mathrm{p}+1$ lags of the error correction term. We use the latter representation. ${ }^{5}$

The long-run restrictions are imposed by constraining the matrix of long-run multipliers, $\mathrm{C}(1)$, as follows:

\footnotetext{
${ }^{5}$ The results are identical if we substitute real wage growth for productivity growth.
} 


$$
C(1)=\left[\begin{array}{lll}
c_{11} & 0 & 0 \\
0 & c_{22} & c_{23} \\
c_{31} & c_{32} & c_{33}
\end{array}\right]
$$

The combination of setting the $c_{1 j}=0$ for $\mathrm{j}=2,3$ and estimating the system in error correction form has the effect of imposing the two long-run constraints with respect to productivity and wages. Conditional on the assumption of cointegration, the overidentifying test for the third restriction is the test that the shock that has a long-run effect on hours is uncorrelated with the technology shock.

In practice, the test must be performed in two steps. The first step estimates the permanent hours shock directly from the bivariate model in equation (7b). The second step uses Generalized Method of Moments (GMM) to estimate system (8). The separately estimated nontechnology shock is used as an additional instrument in the productivity equation, since it should be uncorrelated with the technology shock.

The test of overidentifying restrictions is based on Hansen's J-statistic with one degree of freedom. For the estimated model in (8), Hansen's J-statistic is 0.117 , with a p-value of 0.73 . There is no evidence against the overidentifying restriction with respect to hours. The formal test supports the results given in the impulse response functions from the bivariate model: all three identification schemes are mutually consistent.

\section{Exogeneity of Identified Technology Shocks}

As argued by Hall (1988) and Evans (1992), the technology shock should not in principle be correlated with other exogenous shocks that are not related to technology. Evans cast doubt on the use of the Solow residual as a measure of technology shocks by showing that money, 
interest rates and government spending Granger-cause the Solow residual. Thus, an additional means to test whether the identified shocks are really technology shocks is to test whether other exogenous variables (which should not be related to technology) are correlated with the shocks.

We consider three sets of dummy variables for shocks that have been used in the literature: Romer and Romer's (1989) monetary indicators, Hoover and Perez's (1994) oil shock dummies, and Ramey and Shapiro's (1998) war dates. Strong cases have been made for the exogeneity of the oil shocks and the war dates, but the exogeneity of the monetary indicators is more controversial. All three of these variables, though, have been shown to have significant effects on GDP. ${ }^{6}$

Table 3 shows test statistics based on regressions of the identified technology shock (estimated from equation (5a) on each of the three sets of dummy variables. In each case, we regress the technology shock on the current value as well as four lags of the dummy variable. We do not include lags of the technology shock in the regression since it is by construction not serially correlated.

As is evident from the p-values on the F-tests, none of the sets of dummy variables is significant in explaining the technology shock. The lowest p-value is for Ramey-Shapiro war dates, but even then the p-value is 0.12 . Hence, there is no evidence that the technology shock

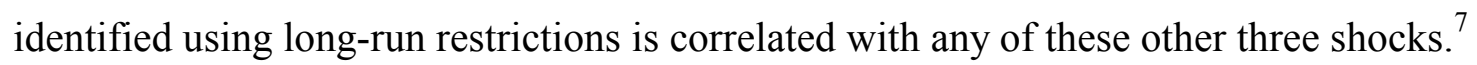

The identified technology shock thus passes the Evans' test. This result provides further support for the plausibility of the shock as a technology shock. The technology shock identified

\footnotetext{
${ }^{6}$ See Ramey and Shapiro (1998) for a comparison of the explanatory power of these variables for GDP.

${ }^{7}$ Hamilton's (1996) net oil increase variable does no better than Hoover-Perez's oil dummy variable in explaining the technology shock.
} 
with these long-run restrictions appears to be a better candidate than the Solow residual for a true technology shock.

\section{E. Evidence from a 5 -Variable Model}

We now study the qualitative effects of these shocks on the wider set of variables discussed in the context of the model. The variables consist of labor productivity, hours, real wages, investment and consumption.

We first conducted an analysis to determine whether there were any other cointegrating relationships in addition to the one between productivity and wages. We studied many possible combinations of the five variables, and determined that the best description of the system was one with two cointegrating vectors and three stochastic trends. The results of the key cointegration tests supporting this conclusion are shown in rows (3) and (4) of Table 2. As row (3) shows, there is strong evidence of a cointegrating relationship between hours, real wages, and consumption. We could find no evidence of cointegration between other variables.

The Johansen test also supports the hypothesis that there are three stochastic trends and two cointegrating vectors in this five variable system. As shown in row 4 of Table 2 , one can reject the hypotheses that there are one or fewer cointegrating vectors, but not the hypothesis that there are less than or equal to two cointegrating vectors.

We therefore specify the five-variable model as follows:

(9a) $y_{t}=C(L) u_{t}$, 


$$
C(1)=\left[\begin{array}{lllll}
c_{11} & 0 & 0 & 0 & 0 \\
c_{12} & c_{22} & c_{23} & c_{24} & c_{25} \\
c_{31} & c_{32} & c_{33} & c_{34} & c_{35} \\
c_{41} & c_{42} & c_{43} & c_{44} & c_{45} \\
c_{51} & c_{52} & c_{53} & c_{54} & c_{55}
\end{array}\right]
$$

$y_{t}$ in equation (9a) is a $5 \times 1$ vector consisting of the labor productivity growth $\left(\Delta x_{t}\right)$, hours growth $\left(\Delta n_{t}\right)$, the error correction term between productivity and wages $\left(x w_{t}\right)$, investment growth $\left(\Delta i_{t}\right)$, and an error correction term involving consumption, hours, and wages $\left(n w c_{t}\right) . u_{t}$ consists of the shocks $\varepsilon_{t}^{z}, \varepsilon_{t}^{m}, \varepsilon_{t}^{w}, \varepsilon_{t}^{i}, \varepsilon_{t}^{c}$, in that order. As a robustness check, we also show results from a system without any allowance for cointegration. In the alternative system, we use only the growth rates of productivity, hours, real wages, investment and consumption.

The zero restrictions in the first row of the matrix of long-run multipliers are the natural extension of Galís restrictions to the larger model. We do not impose the additional restriction with respect to the long-run effect of productivity on hours; the results are similar in either case.

Figures $2 \mathrm{~A}, 2 \mathrm{~B}$, and $2 \mathrm{C}$ show the effect of the identified technology shock on the logs of productivity, labor input, private output, real product wage, investment, and consumption. (The $\log$ of output is simply the sum of the log of productivity and the $\log$ of labor input.) Figure 2A is produced from the VECM with the two estimated cointegrating terms shown in Table 2. We call this specification the "baseline VECM." Figure 2B is produced from the VECM in which we impose the theoretical cointegrating vector of productivity and wages of $(1,-1){ }^{8}$ We refer to this specification as the "labor share VECM." Figure $2 \mathrm{C}$ is produced from the system estimated in first-differences.

\footnotetext{
${ }^{8} \mathrm{We}$ continue to use the estimated cointegrating vector for the hours, wages and consumption.
} 
The results are mostly similar across the three specifications. Consistent with the bivariate results, the shock raises productivity and real wages permanently, and lowers hours in the short-run. In the baseline VECM, the real wage response lags the productivity response. In the labor share VECM and the first-difference specification, real wages and productivity both jump immediately and follow very similar paths. In all specifications, output rises, but by less than productivity in the short-run. The decline in labor is not enough to offset the rise in productivity.

The investment graphs shows the impact of a positive identified technology shock on investment, defined as gross private investment, which includes nonresidential, residential and inventory investment. Investment rises during the first year after the shock, with the rise being stronger in the baseline VECM in Figure 2A. This response is qualitatively in line with the theoretical model. The positive technology shock raises the productivity of capital, inducing firms to raise the level of their capital stock. The sluggishness of the short-run response seems to suggest some type of adjustment cost.

A permanent positive technology shock raises wealth and thus should raise consumption in the long-run. Basu, Kimball, and Fernald show that their estimate of the technology shock leads to no change in consumption on impact, and then a slow rise. Here we find that consumption jumps a small amount initially and then rises to a permanently higher level. This response is consistent with a permanent technology shock. The slow adjustment of consumption suggests some kind of adjustment cost and/or high real interest rates.

To summarize, all of the results shown in this section serve to support the plausibility of interpreting the shock as a technology shock. The use of alternative long-run restrictions for 
identifying the technology shock leads to qualitatively similar results. The shocks appear to be uncorrelated with other key exogenous variables. Furthermore, the effect of the technology shock on key variables such as wages, consumption and investment is in line with those that we would expect. The only result at odds with the standard RBC model is the negative effect of the shock on labor input. The next section will examine whether the standard model can be modified to produce these results.

\section{Two DGE Models with Negative Technology-Hours Correlations}

Galí (1999) and Basu, Kimball and Fernald (1999) suggest that the negative correlation between the technology shock and labor input is evidence in favor of a sticky-price model. In a sticky-price model, a positive technology shock can lead to a decline in labor input if the monetary authority is not too accomodative. Stickiness of prices implies that aggregate demand cannot change immediately. Since demand does not increase, firms can meet demand with fewer workers since their productivity has increased.

But sticky-price models are not the only types of models that can produce the negative correlation. In this section, we offer two examples of DGE models with flexible prices that also imply a negative correlation between technology shocks and labor input. The first model uses habit formation in consumption combined with adjustment costs in investment. The second model changes the production technology so that it is closer to Leontief in the short-run. It is interesting to note that the first of these models had been previously dismissed in the literature because the implied negative correlation between technology and labor was "counterfactual." The previous empirical results suggest that the model's predictions are completely in line with the "facts." 


\section{A. Model 1: Habit Formation in Consumption and Adjustment Costs on Investment}

Previous work by Jermann (1998) and Boldrin, Christiano, and Fisher (2001) has used models with habit formation in consumption and adjustment costs in investment to study asset pricing in production economies. Jermann incorporates habit formation in preferences and capital adjustment costs in order to explain the equity premium and the average risk-free rate observed in the data. His model assumes no utility from leisure, so employment does not fluctuate. Boldrin, Christiano and Fisher and Lettau and Uhlig (2000) criticize Jerman's model because once employment is allowed to fluctuate, it produces a persistently negative response of hours worked to a positive technology shock, which they argue is counterfactual. In light of the previous empirical results, this implication is not counterfactual. We will now explore how the combination of habit persistence in consumption and adjustment costs in investment produces responses that are consistent with the empirical impulse response functions.

The model takes the following form:

$$
\begin{array}{ll}
E_{0} \sum_{t=0}^{\infty} \beta^{t}\left[\log \left(C_{t}-b C_{t-1}\right)-N_{t}\right], \quad 0<\beta<1, b \geq 0 & \text { Preferences } \\
Y_{t}=A_{t} N_{t}^{\alpha} K_{t}^{1-\alpha}, \quad 0<\alpha<1 & \text { Technology } \\
Y_{t}=C_{t}+I_{t} & \text { Resource constraint } \\
K_{t+1}=(1-\delta) K_{t}+\phi\left(\frac{I_{t}}{K_{t}}\right) K_{t} & \text { Capital accumulation } \\
\text { where } \phi\left(\frac{I_{t}}{K_{t}}\right)=\frac{a_{1}}{1-\theta}\left(\frac{I_{t}}{K_{t}}\right)^{1-\theta}+a_{2} &
\end{array}
$$


In the first equation, $C_{t}$ denotes consumption in period t, $N_{t}$ denotes hours worked, and the E denotes conditional expectations. The term $b C_{t}$ is the household's habit stock. In our specification, setting $b=0$ recovers the standard type of preferences.

The economy's technology and resource constraints are given by the standard equations:

where $Y_{t}$ denotes output, $A_{t}$ denotes technology, $K_{t}$ is the capital at the beginning of period t, and $I_{t}$ is investment. In the capital accumulation equation the function $\phi$, which is positive and concave in the investment-capital ratio, captures the capital adjustment costs. If $\theta=0$, then this part of the model collapses to the standard equation of motion for capital. If $\theta$ is positive, then there are adjustment costs to changing the capital stock too rapidly. In this case, Tobin's $q$ can deviate from unity.

In sum, this model deviates from the standard DGE model in two ways: habit formation in preferences and adjustment costs on capital. Otherwise, the model is very standard.

We calibrate the model along the lines of Boldrin et al. (2001), who were trying to match the asset pricing facts. We set the following values for the key parameters:

\section{Calibrated Parameters}

$\begin{array}{llll}\text { Parameter } & \text { Value } & \text { Parameter } & \text { Value } \\ \beta & 0.99 & \mathrm{~b} & 0.9 \\ \delta & 0.021 & \theta & 4.348 \\ \alpha & 0.64 & & \end{array}$

We set $a_{1}$ and $a_{2}$ so that the balanced growth path is invariant to the value of $\theta$. In particular, we set $a_{1}=\delta^{\theta}$ and $a_{2}=-\frac{\delta \cdot \theta}{1-\theta}$ 
The parameters in the first column represent standard parameterizations of an $\mathrm{RBC}$ model. The parameters in the second column represent parameters special to the modifications we made. Following Jermann and Boldrin et al, we set the habit persistence parameter very high at 0.9 and the adjustment cost parameter very high, at over $4 .^{9}$

In order to compare the predictions of the model to the results from the data, we investigate the effect of a permanent, unanticipated jump in the technology variable $A$. We compare the responses of key variables to this shock in our model to those from a standard RBC model with $b=0$ and $\theta=0$.

Figure 3 shows the paths of the technology variable, output, hours, the real wage, consumption, and investment. All variables shown are in logarithms and are normalized to be zero in the pre-shock period. Consider first the responses of output and investment. As the graphs make clear, the modified model produces slower responses of these variables relative to the standard model. In the modified model, consumption does not jump up at all, but increases only gradually. Thus, output, investment and consumption all respond more sluggishly than in the standard model.

In contrast, hours and wages respond more dramatically, and in different ways, in the modified model. In the standard model, hours rise temporarily in response to a positive technology shock. This rise in hours occurs because the substitution effect due to higher wages and real interest rates outweighs the wealth effect in short-run. (In the long-run, they exactly offset each other so the level of hours returns to its previous value.) The opposite is true in the modified model. The level of hours falls temporarily in response to a positive technology shock.

\footnotetext{
${ }^{9}$ Actually, both Jermann and Boldrin et al refer to an adjustment cost parameter $\xi$, which is equal to the inverse of our $\theta$. They set $\xi$ equal to 0.23 , so we set $\theta=1 / 0.23$.
} 
Thus, in the modified model consumption and hours move in the opposite direction. In both cases, the real wage rises, but it rises more in the short-run in the modified model.

The modified model produces responses that are broadly consistent with the empirical results shown in the last section. In particular, both show a gradual, but permanent, rise in output, investment and consumption. Both show an immediate rise in productivity and real wages. Finally, both show a drop in hours worked in response to a positive technology shock. ${ }^{10}$

Why is the response of hours worked so different from the response in a standard RBC model? In the standard model, the wealth effect has an immediate impact on consumption; the only reason consumption does not immediately jump to its new steady-state level is that real interest rates are temporarily high. In the modified model, habit persistence induces a sluggishness in the response of consumption. Consumers prefer not to change their consumption by too much. The natural alternative would be to put the extra resources into investment. However, the high adjustment cost on investment makes investment a relatively expensive good in the short-run. Thus, the households "spend" the new wealth on the only remaining alternative: leisure. Leisure has also become more expensive (because of the increased real wage), but with our calibration it is less expensive than investment.

To illustrate how important each modification is to obtaining the results, Figure 4 shows the simulation results from three models: (1) Our modified model $(\mathrm{b}=0.9$ and $\theta=4.348)$; (2) A model with just habit persistence ( $b=0.9$ and $\theta=0$ ); and (3) A model with just adjustment costs on investment ( $b=0$ and $\theta=4.348$ ). Comparing results of the three models gives us a feel as to how the negative impact of a technology shock is generated.

\footnotetext{
${ }^{10}$ The graphs show the responses out to 20 quarters. Not shown in the graphs is the fact that the labor supply rebounds in the intermediate-run, so that labor supply rises temporarily above the long-run level.
} 
The graph makes clear that it is the combined sluggishness in investment (due to investment adjustment costs ) and consumption (due to habit persistence) that drives the decline in labor. Without both effects, labor either rises or declines very little. The differences in the paths of real wages are caused by the differential labor supply response. Not surprisingly, real wages rise the most when labor supply falls the most.

The high values of $b$ and $\theta$ are not necessary to generate the negative response of labor. For example, a model with $b=0.5$ and $\theta=2$ generates a fall in hours for almost two years. The drop in hours on impact is 2.5 percent for a five percent positive technology shock.

Therefore, a model with habit formation in consumption and adjustment costs in investment can match the effects of a technology shock in the data. In particular, the model can explain the empirically observed drop in labor input after a technology shock. It does so with types of frictions that are fairly well supported in the literature, i.e. adjustment costs on investment and habit persistence in consumption.

Before turning to a model that features a modification to the production technology, it is important to note that there are other modifications to preferences that can lead to a negative correlation between technology and hours. For example, Campbell and Ludvigson (2001) present a model with home production that allows a low intertemporal elasticity of substitution in consumption to be consistent with balanced growth. This low intertemporal elasticity of substitution combined with a highly persistent technology shock produces a negative correlation between technology and hours worked. Campbell and Ludvigson state that this prediction is a fundamental difficulty of the model. Once again, in light of the empirical results it should be considered a strength of the model. 


\section{B. Model 2: A Leontief Model with Labor-Saving Technology Shocks}

In this section, we explore the effects of labor-saving technology shocks when the shortrun production function features fixed proportions. Although the negative relationship between hours and technology is easily reproduced in a simple model, we explore a slightly more general version because of its improved predictions for wages. In particular, we use a one-sector version of the variable-utilization model employed by Ramey and Shapiro (1998) to study the effects of military buildups.

The model takes the following form:

$$
\begin{array}{ll}
Y_{t}=\left(1+S_{t}\right) \cdot \min \left(\frac{N_{t}}{\alpha_{n}}, \frac{K_{t}}{\alpha_{k}}\right) & \text { Production Function } \\
K_{t+1}=(1-\delta) K_{t}+I_{t} & \text { Capital Accumulation } \\
C_{t}+I_{t} \leq Y_{t} & \text { Resource Constraint } \\
V=E_{0} \sum_{t=0}^{\infty}(1+\rho)^{-t}\left\{\log \left(C_{t}\right)+2 \cdot \log \left(T-L_{t}\right)-\theta \cdot N_{t} S_{t}^{2}\right\} & \\
\text { where } L_{t}=\left(1+S_{t}\right) N_{t} & \text { Utility }
\end{array}
$$

The specification of technology implies that at any instant in time, workers $(\mathrm{N})$ and machines $(\mathrm{K})$ must be combined in fixed proportions; for example, one worker is combined with one machine. Thus, firms can increase output within the period only by increasing the workweek of capital. The workweek of capital is given by $(1+\mathrm{S})$, where the standard 40 hour workweek has been normalized to unity, so that $\mathrm{S}$ is the proportion relative to the standard week.

The preferences we specify are standard, except for the addition of a term that involves hours beyond the standard workweek. In this specification, hours worked outside the standard 
daytime hours generate disutility. In addition to the standard effects of a decline in leisure, nonstandard hours generate increasing marginal disutility. Ramey and Shapiro (1998) discuss the empirical justification for these preferences.

We choose values of the parameters to match capital-output ratios and estimated overtime premia. In the production function, we set initial values so $\alpha_{\mathrm{n}}=\alpha_{\mathrm{k}}=8$. In the preference specification, we set $\theta=0.05$ and $\mathrm{T}=50$. The quarterly discount factor $\beta$ is set equal to 0.99 and the depreciation rate to 0.021 . These values generate an overtime premium of 33 percent and a value of $S$ equal to 0.172 in the steady-state. Using this model, we explore the effect of an unanticipated permanent five percent decline in the value of $\alpha_{\mathrm{n}}$ from 8 to 7.6. The decline in $\alpha_{\mathrm{n}}$ implies that fewer workers are needed to operate each machine.

Figure 5 shows the results of the simulations. All variables shown are in logarithms and are normalized to be zero in the pre-shock period. The path of technology shows the path of $1 / \alpha_{\mathrm{n}}$.

Output shows a small amount of sluggishness relative to the RBC model, whereas consumption shows substantial sluggishness. In fact, consumption dips slightly on impact. The source of the slow rise of consumption is the high real interest rate. The shock to labor saving technology raises the marginal product of capital, leading to higher desired investment. The limited opportunities to extend the workweek of capital dampen the output response, so consumption must rise by less than it would in the standard model.

The behavior of hours is the key result. Total hours fall in response to the labor-saving technology shock. To save space, we did not plot the components of hours: the number of workers versus hours per worker. We find that the number of workers falls in response to the 
shock whereas hours per worker rises, through shift or overtime hours. For the given calibration, the first effect dominates the second effect so that total hours falls.

How can real wages rise in the face of declining hours? The reason for the rise in wages in the face of declining hours is the increased use of shifts or overtime in order to extend the workweek of capital. Because shift or overtime work demands a premium (owing to the nature of the utility function), average wages per hour worked rises even though total hours worked falls. In the simple Leontief model with no shifts, real wages and consumption fall.

To summarize, the models we have presented in this section demonstrate that modifications to either preferences or the substitution possibilities between capital and labor can produce a negative correlation between hours and technology. None of these models require sticky prices or wages to produce the results.

\section{Sticky Price Explanations versus Adjustment Cost and Habit Persistence Explanations}

As mentioned earlier, Galí (1999) and Basu, Kimball and Fernald (1999) suggest that the negative correlation between the technology shock and labor input is evidence in favor of a sticky-price model. Galí (1999) presents a stylized static model of sticky prices to illustrate how that class of models can produce a negative correlation between technology shocks and labor input. In his version, in the face of a positive productivity shock but unchanged aggregate demand, firms need fewer workers to produce the same amount of output. Thus, labor demand falls.

The results also hold up in some more complete dynamic models with sticky prices, but the mechanism changes somewhat. King and Wolman (1996) and Dotsey (1999) also obtain a 
negative effect of technology shocks on labor in the short-run in certain models. King and Wolman use Calvo-type (1983) random price adjustment, whereas Dotsey uses staggered price contracts. Both papers show that if the monetary authority targets the money supply, a positive technology shock causes labor input to drop. After a positive productivity shock, firms' markups rise, so there is a greater wedge between the marginal productivity of labor and the real wage. Because the wedge is expected to decrease over time, real wages are expected to rise in the future, so individuals reduce their labor supply in the short-run due to the intertemporal substitution effect. ${ }^{11}$

Both of our models and the dynamic sticky price model predict a fall in hours in the short-run. The mechanism by which this effect occurs is very different, though. In the dynamic sticky price model, hours fall because current wages are low relative to expected future wages. In the habit formation-adjustment cost model, hours fall because leisure is the only variable that can respond significantly to the wealth effect of the technology shock in the short-run. In the Leontief model, hours also fall because current wages are low relative to expected future wages.

In the habit formation-adjustment cost model, real wages jump so far on impact that they actually overshoot their long-run level slightly. In contrast, in the sticky price model (shown in King and Wolman's Figure 6F) real wages do not adjust at all on impact, and then rise steeply during the ten quarters when labor input is below normal. There is a similar pattern in the Leontief model. It is the steep rise of wages that is the key to the reduction in labor supply.

Thus, the three types of models differ in their predictions for the path of wages. Unfortunately, the empirical results are not precise enough to allow us to distinguish between the

\footnotetext{
${ }^{11}$ It is important to note, however, that these papers find that labor input rises under all other monetary policy rules investigated. For example, monetary rules based on inflation targeting, Taylor rules, and Clarida, Gali and Gertler's estimate of the Volker-Greenspan rule all imply that labor input rises in response to a positive technology shock, even in the face of sticky prices.
} 
models. The first-difference specifications in Figure 1B and Figure 2B, as well as the VECM labor share specification in Figure A1, show that real wages jump immediately and follow the path of productivity, which is more consistent with the habit formation-adjustment cost model. On the other hand, the impulse response functions based on the VECM with the estimated cointegrating vector in Figure 2A show a slower response of real wages, favoring the sticky price model and Leontief model.

The responses of the other variables are qualitatively similar across the models and the data. ${ }^{12}$ Figure 6 of King and Wolman (1996) shows the responses of a variety of variables to a positive technology shock. Most of the other variables' responses from the model accord well with our impulse responses shown above. For example, output, consumption, and investment rise gradually in response to a positive technology shock.

In sum, both a sticky price model and modified DGE models have similar implications for the responses of labor input, output, consumption, and investment to a technology shock. They differ in their implications for real wages. The sticky price model and Leontief model predict a gradual response of wages, whereas the habit formation-adjustment cost model predicts that wages jump immediately. The data do not give robust results on the latter response.

\section{Non-Technology Shocks}

In the last section, we showed that a DGE model can be modified to replicate the negative effect of technology shocks on labor input. This modification does not, however, resuscitate technology shocks as a source of business cycles.

\footnotetext{
${ }^{12}$ The only exception is the immediate jump in investment in the Leontief model. Adding investment adjustment costs to the model would bring the response of investment closer to the data.
} 
Galí argues that it is the shock to the labor equation that produces results that look like business cycles. He shows that this shock, which he calls a "demand shock," leads to a rise in output and labor, as well as a temporary rise in productivity, which is consistent with the stylized facts of business cycles. Most of the business cycle movements in output and labor over the post-war are attributable to the demand shock rather than the technology shock.

Since this shock is potentially "the business cycle shock," we conclude this paper with a brief analysis of its properties. Galí identifies the demand shock in a bivariate model as the shock to the labor equation that is uncorrelated with the technology shock. As a start, we use the labor shock estimated from the bivariate model in equation (5), testing whether this shock is correlated with the war, oil and monetary indicator variables.

Recall that none of these variables was correlated with the technology shock. The results are very different in the case of the labor shock, as shown in Table 4. One can overwhelmingly reject the hypothesis that the Hoover-Perez oil dates and the Ramey-Shapiro war dates are not correlated with the shocks. On the other hand, one cannot reject the hypothesis that the Romer monetary dates do not have any explanatory power.

The oil dates and war dates variables explain a surprisingly large fraction of the labor equation shock. When both dates are included, the R-squared of the regression is 0.19 . Thus, almost 20 percent of the variation in what appears to be a key business cycle shock is explained by political events that affect oil prices and defense spending.

Finally, we investigate the effect of the labor shock in our five variable baseline VECM. For comparability with the bivariate model, we impose a Choleski decomposition so that hours are ordered before the three error correction terms. That is, in system (9) we impose the restrictions that $C^{2 j}(0)=0$ for $\mathrm{j}=3,4,5$ in order to identify $\varepsilon^{m}$ as the labor equation shock. 
Figure 6 shows the impulse response to a labor equation shock. The responses of productivity, output and hours are very similar to those from Galí's work. In particular, productivity rises temporarily for less than a year, and output and hours rise with a hump-shaped pattern. The new variables added in our system are real wages, consumption, and investment. Investment and consumption rise, along with output and hours. Real wages fall, however, in response to the labor shock. The labor shock appears to have only temporary effects, since all variables return to close to pre-shock levels within a year or two.

What kind of shock would lead to this pattern of responses? The patterns in the responses implicate one particular type of shock: a shock to the marginal rate of substitution between consumption and leisure. The rise in output, hours, consumption and investment in the face of declining wages is consistent with a shock that decreases the marginal utility of leisure. The labor supply curve shifts out, real wages fall, and firms invest more. The temporary blip in productivity could be accounted for by a rise in effort or capital utilization.

This interpretation is consistent with the conclusions of Shapiro and Watson (1988). Using somewhat different identifying assumptions they find that permanent shocks to labor supply are a major source of business cycles, accounting for 40 percent of the 8 quarter ahead variability in output. They do not include real wages in their model.

In his discussion of Shapiro and Watson, Hall (1988) expressed extreme skepticism about this conclusion. Ironically, nine years later Hall (1997) uncovered a very similar result. He decomposed the driving forces of business cycles based on a distinction between atemporal and intertemporal effects of shocks. These results led him to conclude: "the prime driving force in fluctuations turns out to be shifts in the marginal rate of substitution between goods and work." Our findings lend further support to this conclusion. 


\section{Conclusions}

When we initially set out on this project, we were somewhat skeptical that the shocks identified using long-run restrictions could plausibly be interpreted as technology shocks. We were surprised to find that further study of the data supported that interpretation. Indeed, what appears to have all of the right properties for a technology shock leads to very un-business cycle like characteristics. Hours move in the opposite direction of output, productivity, consumption and investment.

Faced with these strong facts, we then investigated whether other modeling devices besides sticky prices could produce these effects. We found that the combination of habit persistence and adjustment costs on investment closely replicate the responses found in the data. Changing the production function to Leontief also led to predictions closer to those of the data.

Finally, we studied the characteristics of the other key shock in the system, the one that produces positive comovements between output, productivity and hours. We found that this shock also raises consumption and investment, but not real wages. Almost 20 percent of the variation in this shock can be explained by simple dummy variables capturing oil events and military events. 


\section{References}

Ahmed, Shaghil and Byung Sam Yoo, "Fiscal Trends in Real Economic Aggregates," Journal of Money, Credit and Banking, 4 (November 1995, Part I): 985-1001.

Basu, Susanto, Miles Kimball, and John Fernald, "Are Technology Improvements Contractionary?" 1999 manuscript.

Baxter, Marianne and Robert King, "Productive Externalities and Business Cycles," November 1991, Federal Reserve Bank of Minneapolis Discussion Paper 53.

"Fiscal Policy in General Equilibrium," American Economic Review 83 (June 1993): 315-334.

Boldrin, Michele, Lawrence J. Christiano and Jonas D.M. Fisher, "Habit Persistence, Asset Returns and the Business Cycle," American Economic Review 91 (March 2001):149-166.

Calvo, Guillermo, "Staggered Prices in a Utility-Maximizing Framework," Journal of Monetary Economics, 12 (1983): 383-398.

Campbell, John Y. and Sydney Ludvigson, "Elasticities of Substitution in Real Business Cycle Models with Home Production," Journal of Money, Credit, and Banking 33 (November 2001): 847-875.

Dotsey, Michael, "Structure From Shocks," August 1999, Federal Reserve Bank of Richmond Working Paper No. 99-6.

Engle, Robert F. and C.W.J. Granger, "Co-Integration and Error Correction: Representation, Estimation, and Testing," Econometrica 55 (1987): 251-76.

Evans, Charles L., "Productivity Shocks and Real Business Cycles," Journal of Monetary Economics 29 (April 1992): 191-208.

Fleischman, Charles A., "The Causes of Business Cycles and the Cyclicality of Real Wages," Board of Governors of Federal Reserve System (2000).

Galí, Jordi, “Technology, Employment, and the Business Cycle: Do Technology Shocks Explain Aggregate Fluctuations," American Economic Review, 89 (March 1999): 249-271.

Gamber, Edward N. and Frederick L. Joutz, "The Dynamic Effects of Aggregate Demand and Supply Disturbances: Comment," American Economic Review, 83 (December 1993): 1387-1393.

277-291. 
Hamilton, James, "This is What Happened to the Oil Price-Macroeconomy Relationship," Journal of Monetary Economics 38 (1996): 215-220.

Hall, Robert E., "The Relation between Price and Marginal Cost in U.S. Industry," Journal of Political Economy 96 (October 1988): 921-947.

, 'Discussion of 'Sources of Business Cycle Fluctuations,' by Shapiro, Matthew D. and Mark Watson," NBER Macroeconomics Annual, 1988, pp. 149-153.

, "Macroeconomic Fluctuations and the Allocation of Time," Journal of Labor Economics 15 (January 1991): S223-S250.

Hoover, Kevin D. and Stephen J. Perez, "Post hoc Ergo Procter Once More: An Evaluation of 'Does Monetary Policy Matter?' in the Spirit of James Tobin," Journal of Monetary Economics 34 (August 1994): 47-74.

Jermann, Urban J., "Asset Pricing in Production Economies," Journal of Monetary Economics 41 (April 1998): 257-276.

Kiley, Michael, "Labor Productivity in U.S. Manufacturing: Does Sectoral Comovement Reflect Technology Shocks?” December 1996 manuscript.

King, Robert, Charles Plosser, James Stock and Mark Watson, "Stochastic Trend and Economic Fluctuations," Working Paper version, 1987.

King, Robert and Sergio T. Rebelo, "Resuscitating Real Business Cycles," in Handbook of Macroeconomics, edited by John B. Taylor and Michael Woodford. Elsevier: Amsterdam, 1999. Volume 1B, pp. 927-1007.

King, Robert G. and Alexander Wolman, "Inflation Targeting in a St. Louis Model of the $21^{\text {st }}$ Century," Federal Reserve Bank of St. Louis Review 78 (May-June 1996): 83-107.

Lettau, Martin and Harald Uhlig, "Can Habit Formation Be Reconciled with Business Cycle Facts?" Review of Economic Dynamics 3 (2000): 79-99.

Ramey, Valerie A. and Matthew D. Shapiro, "Costly Capital Reallocation and the Effects of Government Spending," Carnegie-Rochester Conference Series on Public Policy, 48 (June 1998): 145-194.

Romer, Christina and David Romer, "Does Monetary Policy Matter? A New Test in the Spirit of Friedman and Schwartz," in Olivier J. Blanchard and Stanley Fischer, eds., NBER Macroeconomics Annual: 1989, 63-129.

Shapiro, Matthew D. and Mark Watson, "Sources of Business Cycle Fluctuations," NBER Macroeconomics Annual, 1988, pp. $111-148$. 
Shea, John, “What Do Technology Shocks Do?” NBER Macroeconomics Annual, 1998, pp. 275310.

Stock, James H. and Mark W. Watson, "Testing for Common Trends," Journal of the American Statistical Association 83 (1988): 1097-1107. 
Table 1: Long-Restrictions Used in the Literature

\begin{tabular}{|c|c|c|c|c|c|}
\hline & $\begin{array}{l}\text { AD shocks } \\
\text { have no } \\
\text { permanent } \\
\text { effect on } \\
\text { output or } \\
\text { hours }\end{array}$ & $\begin{array}{l}\text { AD shocks } \\
\text { have no } \\
\text { permanent } \\
\text { effects on } \\
\text { real wages }\end{array}$ & $\begin{array}{l}\text { Technology } \\
\text { shocks have no } \\
\text { permanent } \\
\text { effect on hours }\end{array}$ & $\begin{array}{l}\text { Only } \\
\text { technology } \\
\text { shocks have a } \\
\text { permanent } \\
\text { effect on } \\
\text { productivity }\end{array}$ & $\begin{array}{l}\text { Only } \\
\text { technology } \\
\text { shocks have a } \\
\text { permanent } \\
\text { effect on real } \\
\text { wages }\end{array}$ \\
\hline $\begin{array}{l}\text { Blanchard- } \\
\text { Quah (1989) }\end{array}$ & $\checkmark$ & & & & \\
\hline $\begin{array}{l}\text { Shapiro- } \\
\text { Watson (1988) }\end{array}$ & $\checkmark$ & & $\checkmark$ & & \\
\hline $\begin{array}{l}\text { Gamber-Joutz } \\
(1993,1997)\end{array}$ & $\checkmark$ & $\checkmark$ & $\checkmark$ & & \\
\hline Galí (1999) & & & & $\checkmark$ & \\
\hline $\begin{array}{l}\text { Fleischman } \\
(2000)\end{array}$ & $\checkmark$ & & $\checkmark$ & $\checkmark$ & $\checkmark$ \\
\hline $\begin{array}{l}\text { Francis-Ramey } \\
\text { (2001) }\end{array}$ & & & $\checkmark$ & $\checkmark$ & $\checkmark$ \\
\hline
\end{tabular}


Table 2: Cointegration Tests

(tests include constant and trend)

\begin{tabular}{|c|c|c|}
\hline System & $\begin{array}{l}\text { P-value for hypothesis tests } \\
\text { (optimal \# of lags included) }\end{array}$ & $\begin{array}{l}\text { Cointegrating vector } \\
\text { (estimated via DOLS) }\end{array}$ \\
\hline 1. $x-w$ & $\begin{array}{l}\mathrm{H}_{0}: x-w \text { has a unit root } \\
\mathrm{P}=0.019 \quad(4 \text { lags })\end{array}$ & \\
\hline 2. $x$ and $w$ & $\begin{array}{l}\mathrm{H}_{0}: \text { No cointegration } \\
\mathrm{p}=0.017 \quad(4 \text { lags })\end{array}$ & $\begin{array}{l}(1,-1.03649) \\
\quad(0.0090)\end{array}$ \\
\hline 3. $n, w$, and $c$ & $\begin{array}{l}\mathrm{H}_{0}: \text { No cointegration } \\
\mathrm{p}=0.003 \quad \text { (7 lags })\end{array}$ & $\begin{array}{l}(1,1.04581,-1.03093) \\
(0.062) \quad(0.067)\end{array}$ \\
\hline 4. $x, n, w, c$ and $i$ & $\begin{array}{l}\text { Johansen test: } r=\# \text { of } \\
\text { cointegrating vectors } \\
\mathrm{H}_{0}: r=0, \quad \mathrm{p}=0.003 \\
\mathrm{H}_{0}: \mathrm{r} \leq 1, \quad \mathrm{p}=0.037 \\
\mathrm{H}_{0}: \mathrm{r} \leq 2, \quad \mathrm{p}=0.189 \\
(2 \text { lags })\end{array}$ & \\
\hline
\end{tabular}

$x=$ labor productivity

$w=$ real product wages

$n=$ hours per capita

$c=$ consumption expenditures per capita

$i=$ gross investment expenditures per capita 
Table 3: Exogeneity Tests

Dependent Variable: Technology Shocks from Bivariate Model

\begin{tabular}{|l|c|c|c|}
\hline & $\begin{array}{c}\text { Romer \& Romer } \\
\text { Monetary Dates }\end{array}$ & $\begin{array}{c}\text { Hoover-Perez Oil } \\
\text { Dates }\end{array}$ & $\begin{array}{c}\text { Ramey-Shapiro War } \\
\text { Dates }\end{array}$ \\
\hline P-value of F-test & 0.366 & 0.939 & 0.122 \\
\hline R-Squared & 0.026 & 0.006 & 0.041 \\
\hline
\end{tabular}

The F-test is based on a regression of the identified technology shock on a constant and current and four quarterly lags of the variable in question. (Lagged values of the technology shock are not included because the technology shock is by construction serially uncorrelated.) The F-test corresponds to the test that all of the coefficients on the dummy variable in question are jointly equal to zero. 
Table 4: Exogeneity Tests

Dependent Variable: Labor Shocks

\begin{tabular}{|l|c|c|c|c|}
\hline & $\begin{array}{c}\text { Romer \& Romer } \\
\text { Monetary Dates }\end{array}$ & $\begin{array}{c}\text { Hoover-Perez Oil } \\
\text { Dates }\end{array}$ & $\begin{array}{c}\text { Ramey-Shapiro } \\
\text { War Dates }\end{array}$ & Oil and War Dates \\
\hline P-value of F-test & 0.295 & 0.000 & 0.033 & 0.000 \\
\hline R-Squared & 0.029 & 0.146 & 0.057 & 0.193 \\
\hline
\end{tabular}

The F-test is based on a regression of the identified labor shock on a constant and current and four quarterly lags of the variable in question. (Lagged values of the labor shock are not included because the labor shock is by construction serially uncorrelated.) The F-test corresponds to the test that all of the coefficients on the dummy variable in question are jointly equal to zero. 
Figure 1: Comparison of Technology Shock Effects Across Identification Schemes (90 percent confidence bands)

A. Only technology shocks can have permanent effects on labor productivity
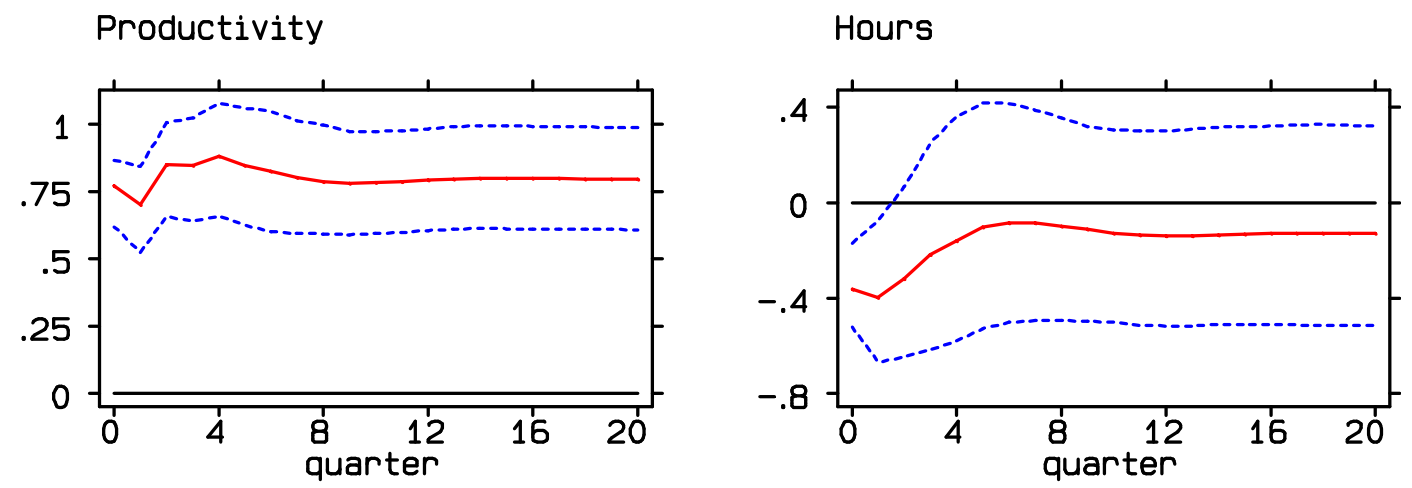

B. Only technology shocks can have permanent effects on real wages.
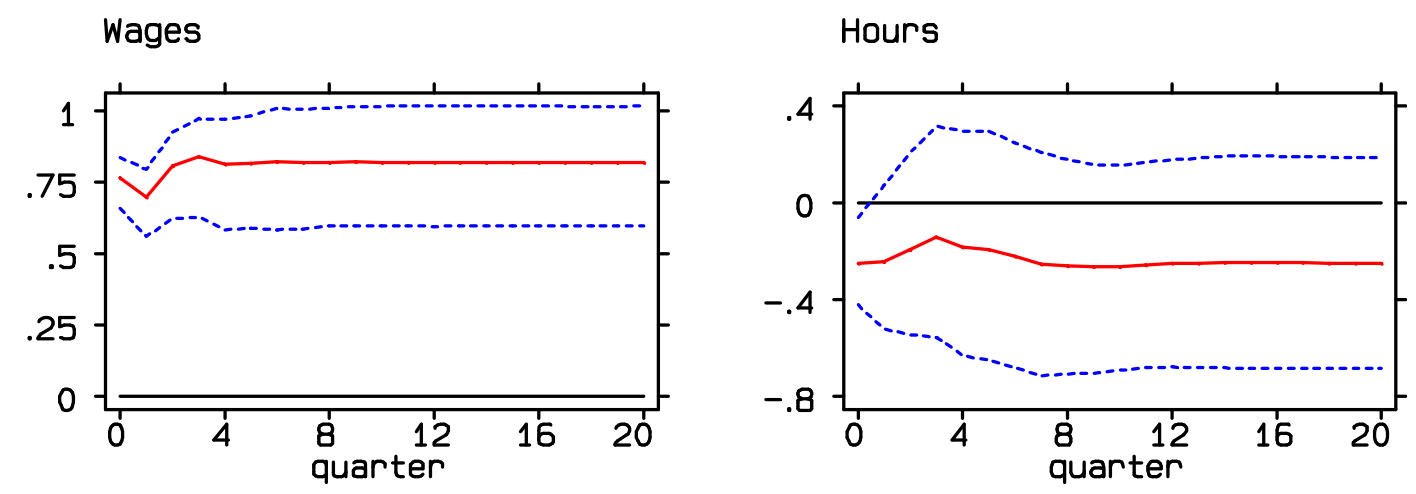

C. Technology shocks cannot have permanent effects on hours.
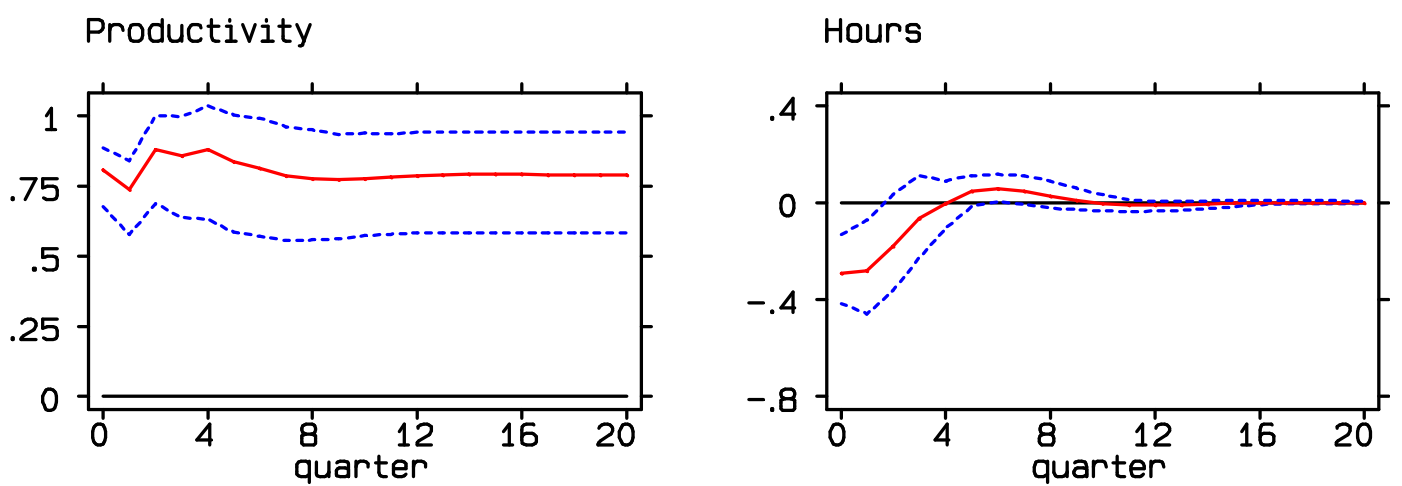
Figure 2A: Impulse Response to a Technology Shock 5-Variable Baseline Vector-Error Correction Model ( 90 percent confidence bands)
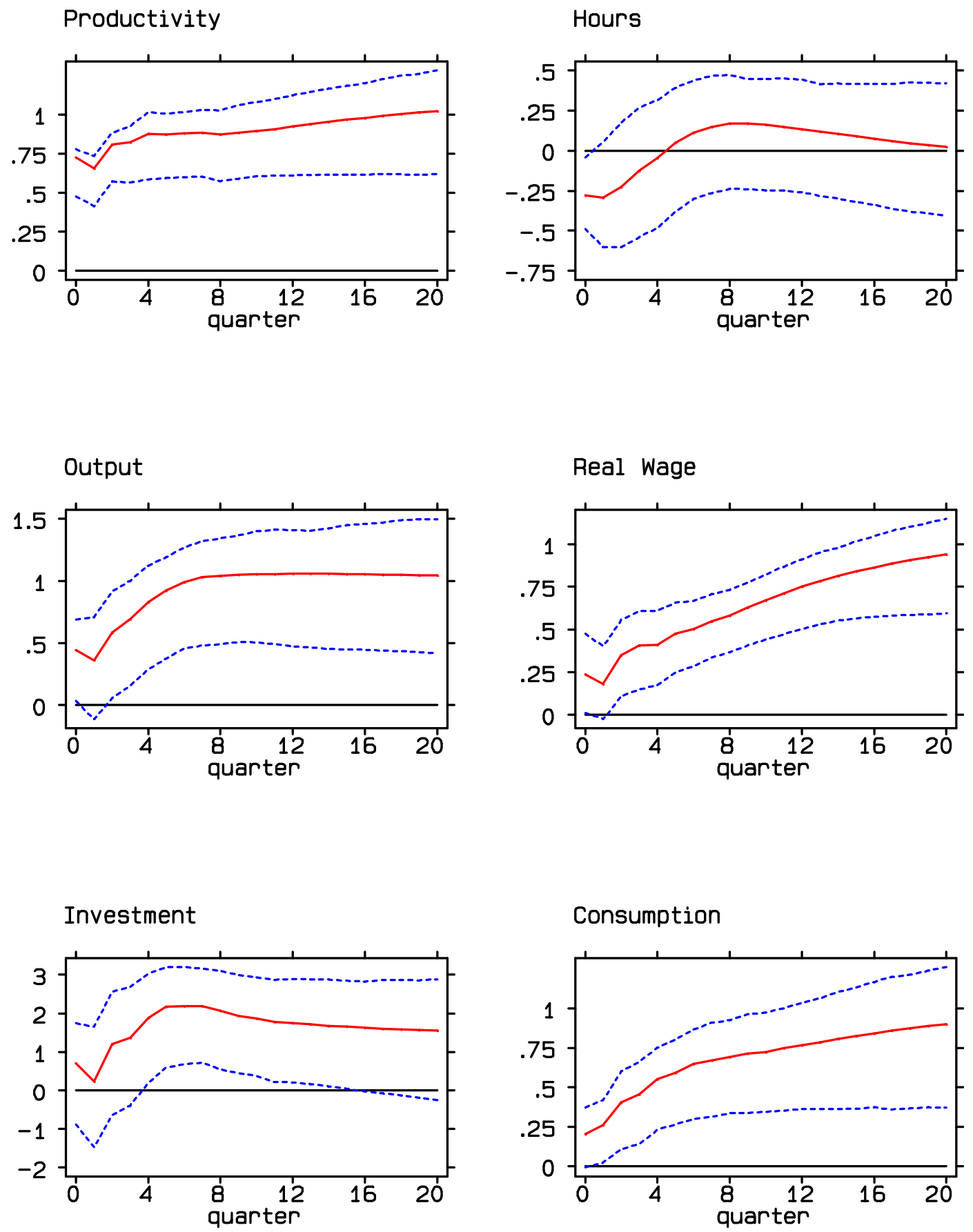
Figure 2B: Impulse Response to a Technology Shock

5 Variable VECM with Labor Share

(90 percent confidence bands)
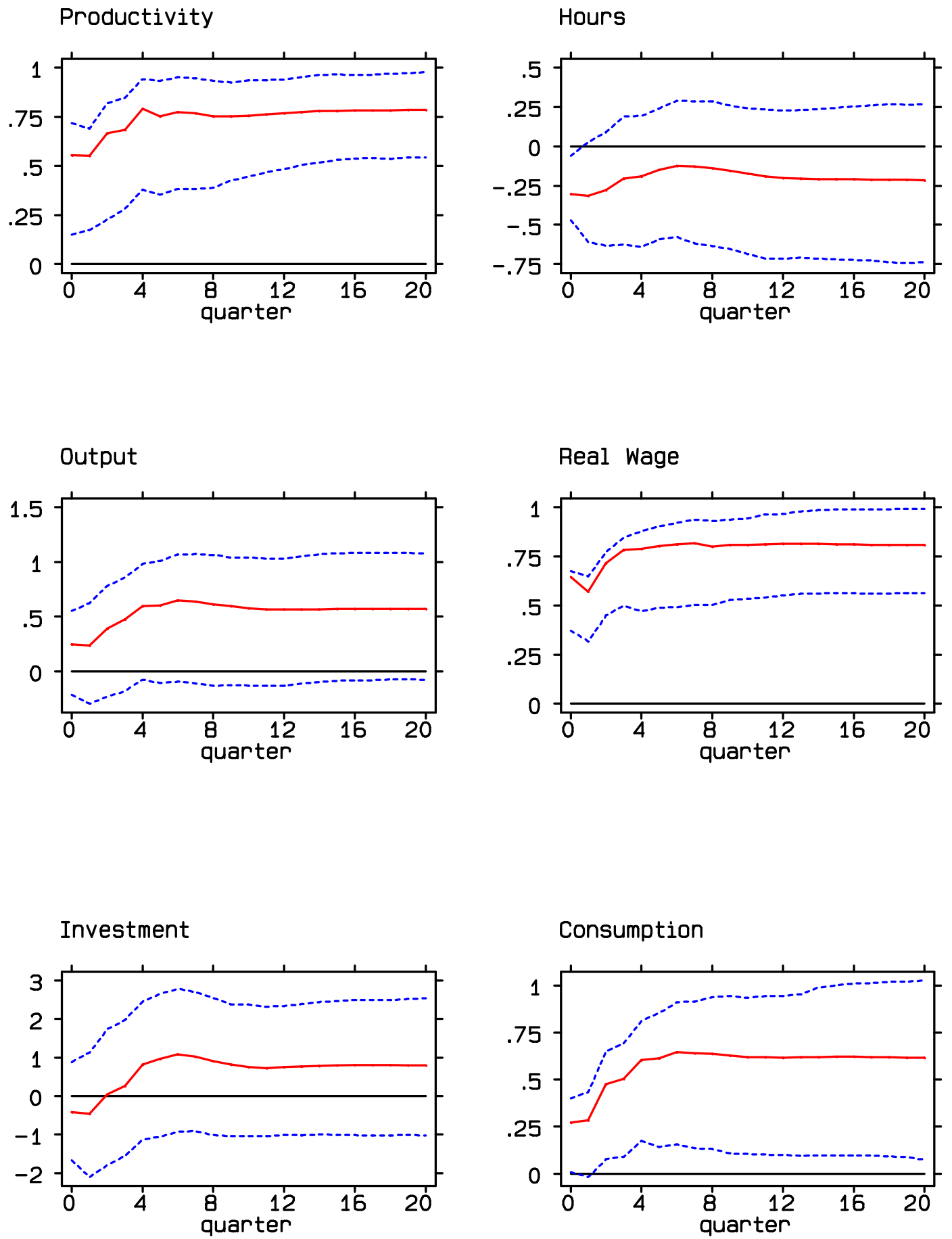
Figure 2C: Impulse Response to a Technology Shock

5 Variable Model, First-Difference Model

(90 percent confidence bands)

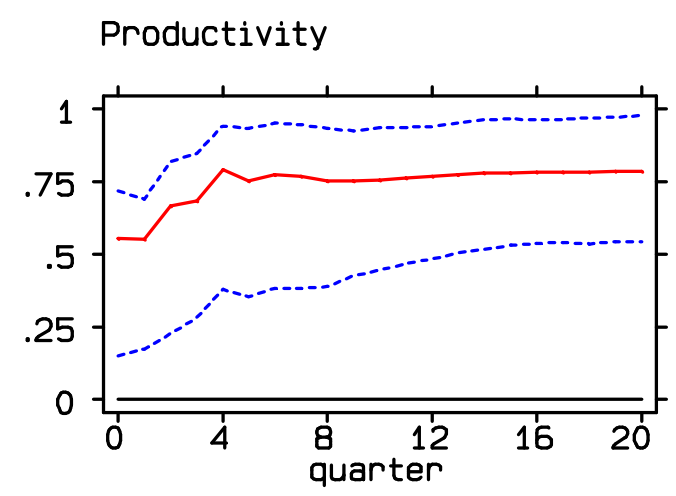

Hours
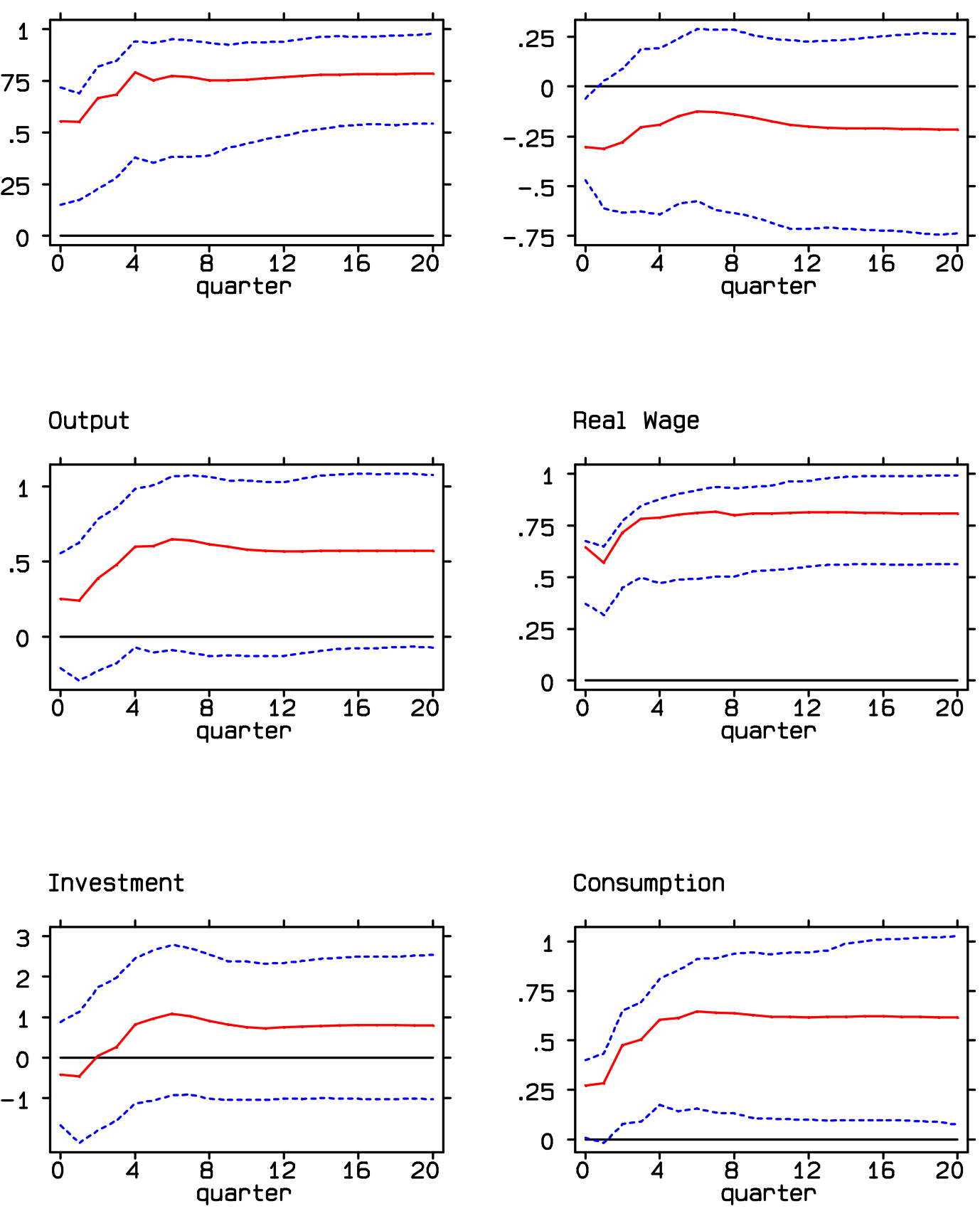
Figure 3: Theoretical Effect of a Positive Technology Shock RBC versus Habit Formation-Investment Adjustment Cost
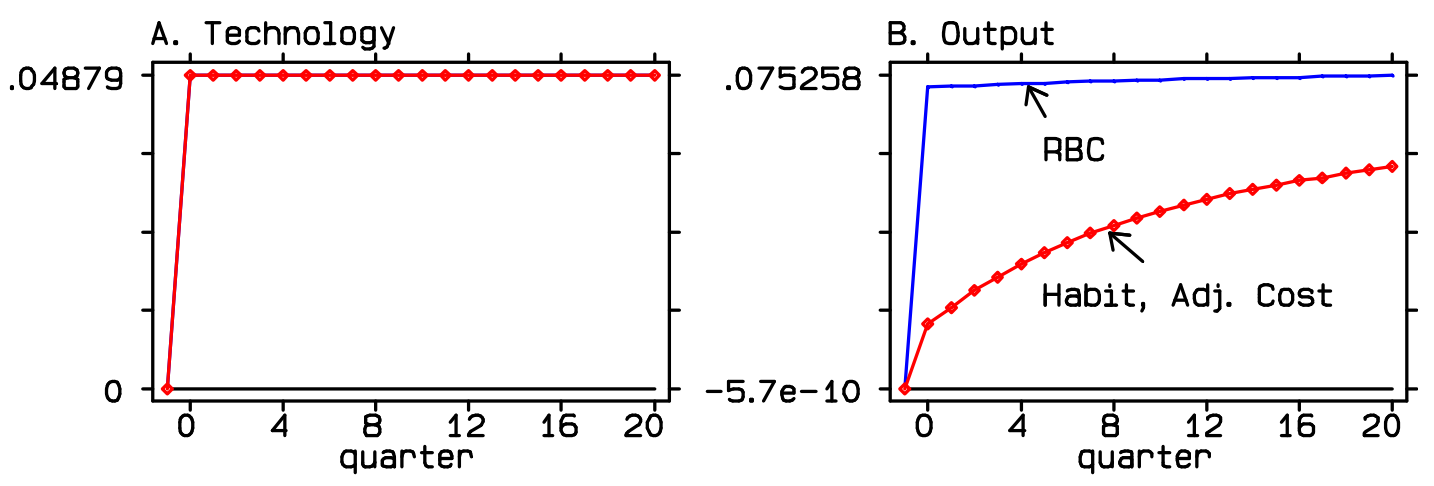

C. Hours

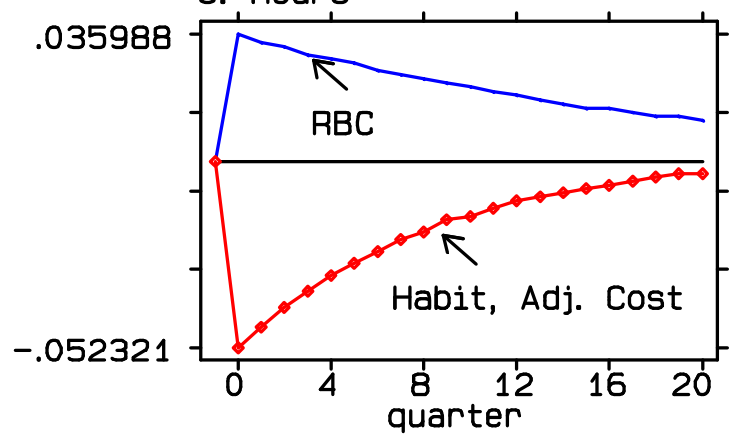

D. Real Wage

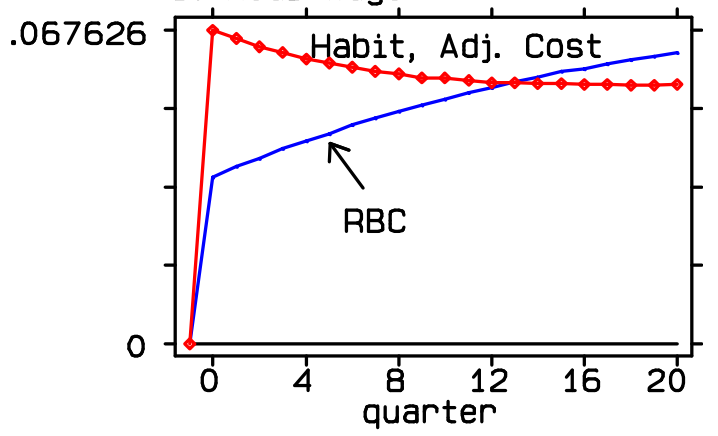

E. Consumption

.062246

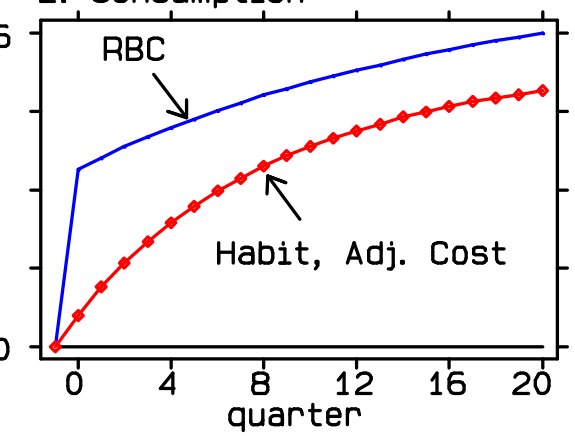

F. Investment

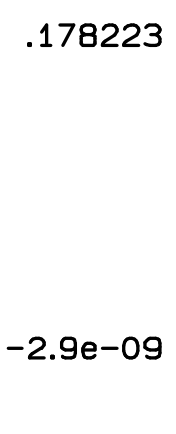

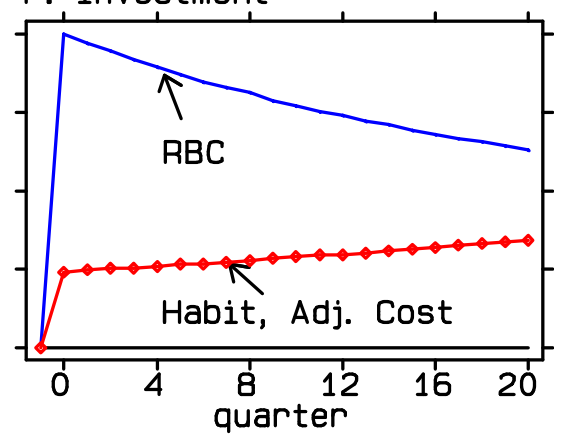




\section{Figure 4}

The Role of Habit Formation in Consumption versus Adjustment Cost in Investment

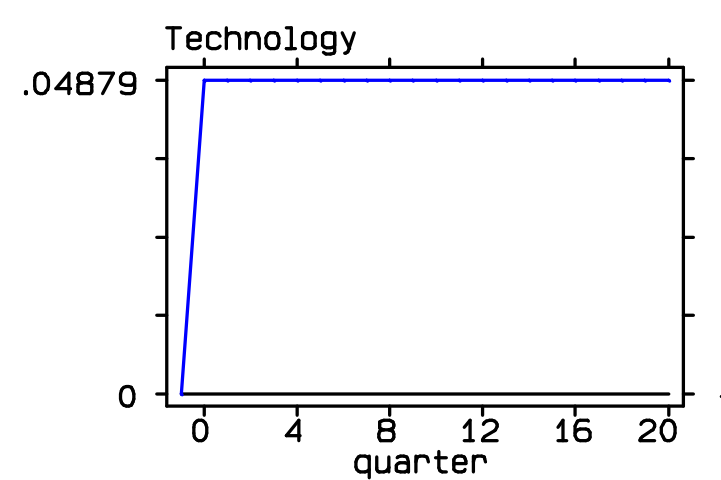

Hours

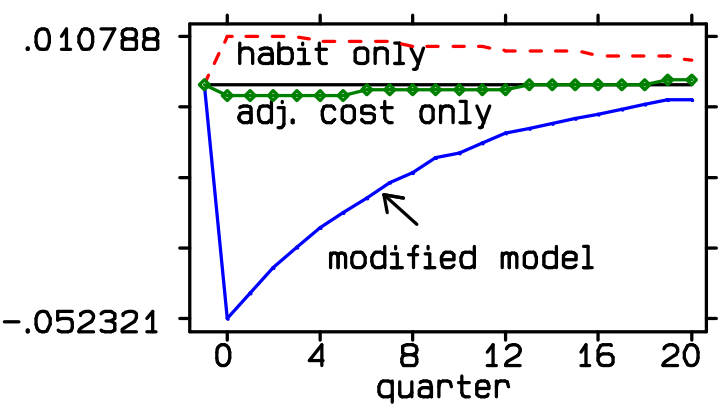

Consumption

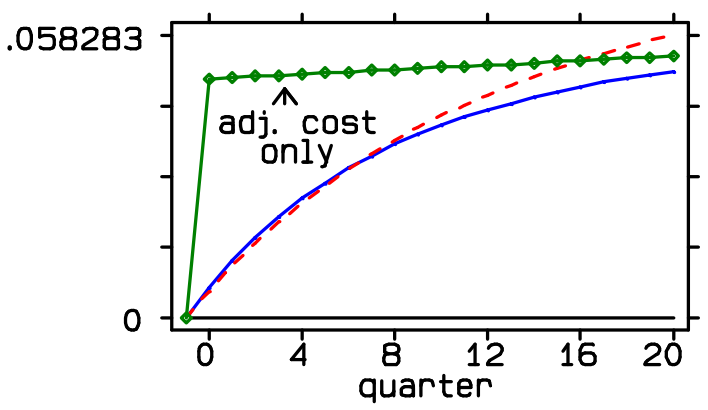

Output

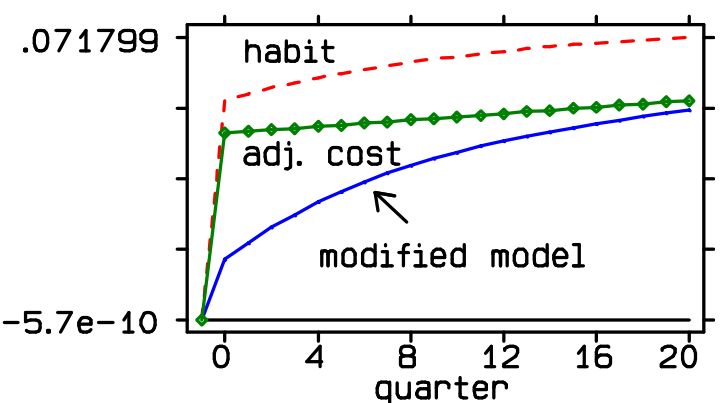

Real Wage

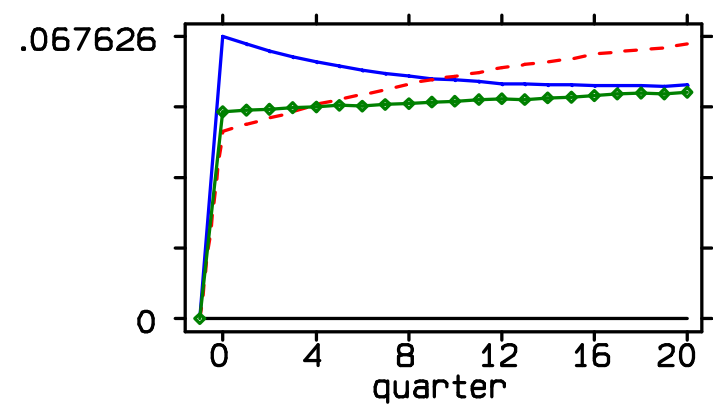

Investment

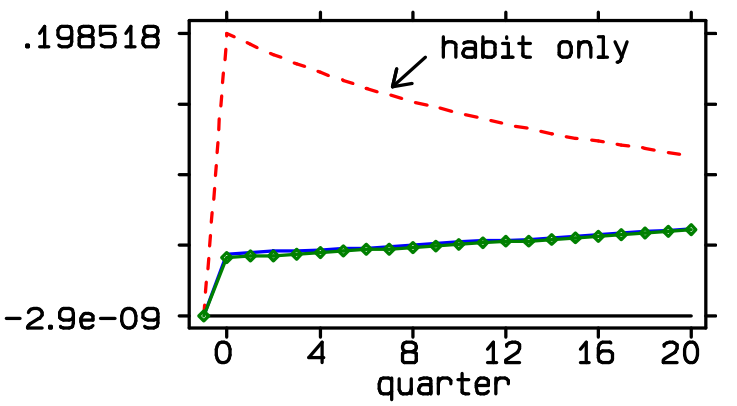


Figure 5: Theoretical Effect of a Positive Technology Shock Leontief Production with Variable Capital Utilization
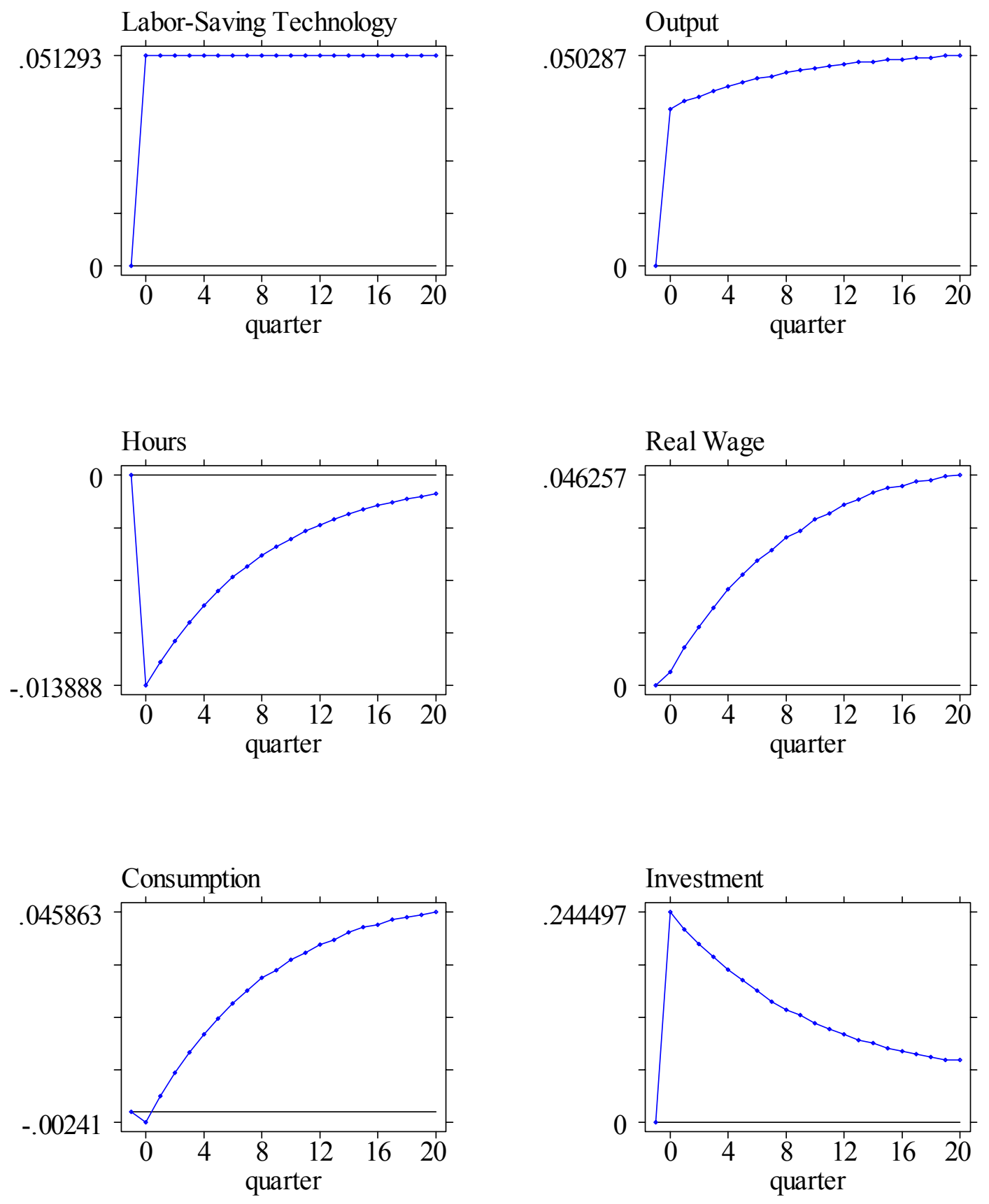
Figure 6: Impulse Response to a Labor Shock: 5 Variable VECM (90 percent confidence bands)
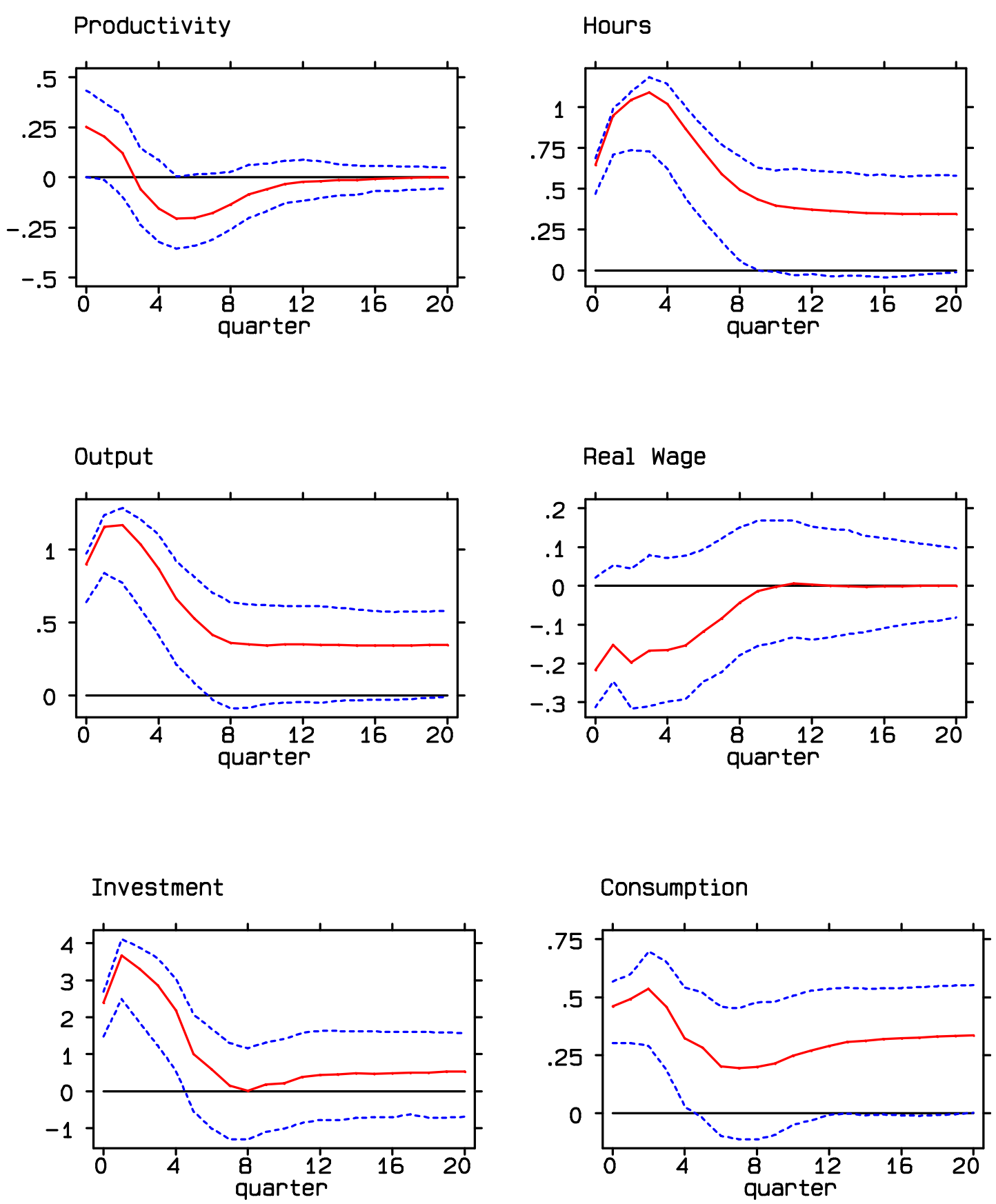